Original article

\title{
Changes of hard dental and bone tissue of alveolar process in rats on the orthodontic tooth movement on the background of an experimental goiter
}

\author{
Kamila A. Kolesnik ${ }^{12}$, Oksana V. Denga ${ }^{1}$, Olga A. Makarenko ${ }^{1}$ \\ ${ }^{1}$ Institute of Stomatology of Ukrainian Academy of Medical Siences, Odessa, Ukraine \\ ${ }^{2}$ Crimean State Medical University n.a. S.I. Georgievsky, Simferopol, Ukraine
}

Received 29 August 2013, Accepted 1 October 2013

(C) 2013, Kolesnik K.A., Denga O.V., Makarenko O.A.

C 2013, Russian Open Medical Journal

\begin{abstract}
Aim of this study was to study the state of dental hard and bone tissues of alveolar process in rats with the model of orthodontic tooth movement at the experimental goiter based on the analysis of bone phosphatases and proteases activity. Material and Methods Experimental study with the model of goiter and orthodontic tooth movement in rats. The experiment was carried out with 30 Wistar rats of gregarious breeding. During the first stage of the experiment the goitre was being simulated by giving $1 \%$ solution of potassium perchlorate with drinking water for 20 days. During the second experimental stage using thiopental the orthodontic model of tooth movement (OMtM) was being reproduced for 21 days. The lower jaw in rats served to reveal carious cavities and atrophy rate of alveolar process, the upper jaw served for determining the common activity of alkaline, acid phosphatase, elastase and total proteolytic activity (OPA), the pulp of incisors served to determine the activity of bone phosphatases. Statistical analysis - One way analysis of variance (ANOVA). Comparison between experimental groups was carried out with the help of t-Student $U$ and Mann-Whitney test (p.asymp.sig<0.05 was considered significant). Results - in animals under experiment the orthodontic tooth movement together with thyroid disorders is accompanied by increased proteases activity of bone tissue and impaired activity of bone phosphatases. Conclusions sudden aggravation in the resorption processes of bone tissue of alveolar process, demineralization of hard dental tissue during the orthodontic tooth movement in relation to experimental goiter show that child with the thyroid gland disorders are in need of active treatment and preventive measures during active apparatus treatment of dentoalveolar anomalies.
\end{abstract}

Keywords: experimental goiter, orthodontics, bone phosphatases, proteinases

Cite as Kolesnik KA, Denga OV, Makarenko OA. Changes of hard dental and bone tissue of alveolar process in rats on the orthodontic tooth movement on the background of an experimental goiter. Russian Open Medical Journal 2014; 3: 0110.

Correspondence to Dr Kamila A. Kolesnik. Address: Department of children's stomatology, Crimean state medical university n.a. S.I. Georgievsky, 5/7, Lenina boulevard, Simferopol, Ukraine. E-mail: nalivkina2009@mail.ru

\section{Introduction}

Contingent of patients was observed by an orthodontist and they were not only healthy children, but also children who had the general diseases of the organism. The structure of children's and teenagers' somatic diseases is closely connected with the thyroid gland pathology [1-3]. Thyroid hormones influence essentially on a structurally-metabolic condition of bone tissue and the intensity of metabolism there [4-6]. The thyroid status disturbance can be reflected on the biological processes which underlie orthodontic tooth movement [7]. Studying has theoretical and practical value because it is connected with a thyroid gland dysfunction which influences on demineralization and demineralization processes in hard tooth tissues, balancing of resorptioned processes and mineralization in bone tissue of an alveolar process at orthodontic teeth transfer valuable. Therefore the purpose of the research is to investigate the condition of rats' hard tooth tissues and bone tissue of an alveolar process with a model of the orthodontic tooth movement at an experimental goiter on the basis of the analysis of the bone phosphatases and proteinases activity.

\section{Material and Methods}

Animals

The experiment on 30 rats of Vistar's line of gregarious breeding (females, 5 months, $210 \pm 28 \mathrm{~g}$ ) was performed. Experimental researches are carried out according to the rules which are provided by Council of the international medical organizations, they are presented in «International References of Carrying out of Medical-biological Researches on Experimental Animals» and "The letter of the commission on ethics problems concerning animals», and the Ukrainian Law «About the Protection of Animals against the Cruel Treatment». The permission for researches has been received at the meeting of Committee on bioethics of State Institution «Institute of Stomatology AMS of Ukraine». 
Stomatology

Table 1. Indicators of caries and atrophy of an alveolar process in rats at modeling of a goiter and orthodontic intervention

\begin{tabular}{|c|c|c|c|c|}
\hline \multicolumn{2}{|c|}{ Groups of animals } & $\begin{array}{l}\text { Degree of atrophy of an } \\
\text { alveolar process, } \%\end{array}$ & $\begin{array}{c}\text { Number of carious cavities, an } \\
\text { average on } 1 \text { rat }\end{array}$ & $\begin{array}{c}\text { Depth of lesions of teeth } \\
\text { caries, points }\end{array}$ \\
\hline \multirow[t]{2}{*}{ The intact } & $\begin{array}{l}\text { Without } \\
\text { OTM }\end{array}$ & $25.1 \pm 0.8$ & $6.3 \pm 0.8$ & $7.3 \pm 0.9$ \\
\hline & OTM & $29.3 \pm 0.3^{1}$ & $5.5 \pm 0.4$ & $6.4 \pm 0.7$ \\
\hline \multirow{2}{*}{$\begin{array}{l}\text { Experimental } \\
\text { goiter }\end{array}$} & $\begin{array}{l}\text { Without } \\
\text { OTM }\end{array}$ & $27.9 \pm 0.9^{1}$ & $8.4 \pm 0.7^{1}$ & $9.8 \pm 0.9^{1}$ \\
\hline & OTM & $32.7 \pm 0.9^{123}$ & $8.9 \pm 0.6^{12}$ & $11.2 \pm 1.1^{12}$ \\
\hline
\end{tabular}

${ }^{1}$ is statistically significant differences $(P<0.05)$ from value in intact group; ${ }^{2}$ is statistically significant differences $(P<0.05)$ from indicators at rats with 0 TM;

${ }^{3}$ is statistically significant differences $(P<0.05)$ from indicators in rats with a goiter without OTM.

Table 2. Influence of an experimental goiter, orthodontic intervention on phosphatases activity of rats' pulps

\begin{tabular}{|c|c|c|c|}
\hline \multicolumn{2}{|c|}{ Groups of animals } & \multirow{2}{*}{$\frac{\text { Activity of acidic phosphatase, } n k a t / g}{0.051 \pm 0.004}$} & \multirow{2}{*}{$\frac{\text { Activity of alkaline phosphatase, } \mathrm{nkat} / \mathrm{g}}{1.75 \pm 0.10}$} \\
\hline The intact & Without OTM & & \\
\hline & OTM & $0.046 \pm 0.003$ & $1.57 \pm 0.09$ \\
\hline The experimental & Without OTM & $0.064 \pm 0.005^{1}$ & $1.40 \pm 0.08^{1}$ \\
\hline goiter & OTM & $0.079 \pm 0.005^{123}$ & $1.36 \pm 0.05^{12}$ \\
\hline
\end{tabular}

\section{Drug}

A standard technique was used for modeling of an experimental goiter; it is the introduction of $1 \%$ solution of potassium per-chlorate with drinking water to rats within 20 days [8]. References testify that $16-20$ days of reception of $1 \%$ solution of potassium per-chlorate in 20 times reduce iodine maintenance in a thyroid gland of experimental animals and causes morphological, functional and hormonal changes in it, characteristic for patients with euthyroid goiter [9].

\section{Experimental study design}

A goiter was modeled at the first stage of the experiment. At the second stage of the experiment under thiopental narcosis $(20 \mathrm{mg} / \mathrm{kg})$ a closing nickel-titanic spring was fixed with the help of a ligature wire on an incisor of the maxilla and a molar tooth and it was reproduced the model of orthodontic tooth movement (OTM) within 21 days. Animals were taken out from the experiment under thiopental narcosis by opening of the great heart vessels. 2 groups of research have been allocated:

i) Intact animals: The first subgroup - the rats which were on a diet of a vivarium $(n=10)$; the second subgroup - the rats which were on a diet of a vivarium and orthodontic tooth movement (OTM) ( $n=5)$;

ii) Rats were with the experimental model of a goiter: The first subgroup - without OTM $(n=10)$; the second subgroup - with OTM $(n=5)$.

\section{Collection of samples}

In rats a mandible was allocated for the calculation of carious cavities and the definition of atrophy degree of an alveolar process, the maxilla - for the definition of alkaline, acidic phosphatase, elastase activity and the general proteolytic activity (GPA), a pulp of incisors - for the definition of the phosphatases activity. Homogenates of bone tissue were prepared from calculation $75 \mathrm{mg} / \mathrm{ml} 0.1 \mathrm{M}$ of the citrate buffer $\mathrm{pH} \mathrm{6.1,} \mathrm{pulps} \mathrm{-}$ $5 \mathrm{mg} / \mathrm{ml}$ of normal saline solution.

\section{Biochemical analysis}

Acidic $(\mathrm{pH} \mathrm{4.8)}$ and alkaline $(\mathrm{pH} 10.5)$ phosphatases activity was estimated with the help of $p$-nitrophenylphosphate reaction as a result of which hydrolysis $p$-nitrophenol of yellow colour was formed. The intensity of coloring is proportional to the activity of enzyme. The general proteolytic activity (GPA) was defined by Kunitz's method in R.D. Barabash's and A.P. Levitsky's modification based on hydrolysis of casein by proteinases at $\mathrm{pH} 7.6$ updating. The quantity of splitting products of casein was proportional to activity of proteinases of bone tissue and it was defined by means of Folin's reagent [10]. The activity of elastase was estimated on hydrolysis of N-t-BOC-L-alanin-p-nitrophenyl ester. The pnitrophenol was splited off from substrate under the influence of elastase and it gave a yellow staining, which intensity was proportional to the activity of enzyme [11].

\section{Statistical analysis}

Statistical analysis was carried out by one way analysis of variance (ANOVA). Comparison between the experimental groups was done using the t-Student $U$ and Mann-Whitney test $(P<0.05$ was considered as significant). Data presented as mean and standard deviation $(\mathrm{M} \pm \mathrm{SD})$.

\section{Results}

\section{The indicators of caries and atrophy of an alveolar process}

In healthy rats after orthodontic intervention it was observed the growth of atrophy of an alveolar process $(P<0.001)$. Also goiter modeling led to the augmentation of the indicator $(P<0.001)$ (Table 1). The highest value of atrophy of an alveolar bone has been registered in animals of the 2 group with OTM on the background of the experimental goiter. This indicator was much higher in comparison with the healthy rats indicators with OTM $\left(P_{1}=0.002\right)$ and the rats with goiter without OTM $\left(P_{2}=0.002\right)$. Modeling of an experimental goiter in rats of the 2 group led to the appreciable growth of quantity and depth of carious lesions on $33.3 \%$ and $34.2 \%$, accordingly $(P<0.05)$. If orthodontic treatment didn't affect on the caries intensity in healthy rats then in rats with 
a goiter the spring fixation led to the growth of number and depth of carious lesions. So, in animals of the second group with OTM the quantity of carious lesions increased to $61.8 \%$ and the depth to $75.0 \%$ in comparison with healthy rats indicators where the animals had the spring fixation $\left(\mathrm{P}_{1}<0.001\right.$ and $\left.\mathrm{P}_{2}=0.002\right)$.

\section{Activity pulps phosphatases of rats' incisors}

In the Table 2 there are research results of activity acidic (AcP) and alkaline phosphatases (AIP) pulps of rats' incisors, which show the application of orthodontic forces and they didn't affect on the activity of both phosphatases of a pulp in healthy rats. The activity levels of those enzymes could attest about the pulp functional condition. Goiter modeling promoted to augmentation of AcP activity in a pulp of incisors on $25.5 \%$, and fixation of an orthodontic spring on the background of an experimental goiter on $54.9 \%(P<0.001)$ in comparison with corresponding indicators in an intact group of animals. The activity of this pulp enzyme was also higher than the values in the pulp of healthy rats on the background OTM $\left(\mathrm{P}_{1}<0.001\right)$ and in the pulp of the rats with the experimental goiter $\left(P_{2}<0.05\right)$. From the data presented in the table it is possible to conclude about the potentiation of the development negative effects of a goiter and an orthodontic intervention on the activity of ACP of a pulp. Simultaneously with augmentation of AcP activity the goiter modeling led to the depression of AlP activity in a pulp on $20.0 \%(P=0.02)$. On the background of a goiter the orthodontic teeth transfer led to the considerable reduction of activity of that enzyme to $22.3 \%$ $\left(P=0.01, P_{1}<0.05\right.$ and $\left.P_{2}>0.6\right)$.

\section{The general proteolytic activity and activity of elastase}

Researches of general proteolytic activity (GPA) (pH 7.6) in bone tissue of an alveolar process testified that in healthy rats OTM led to augmentation GPA in an alveolar bone on $46.0 \%$ $(P<0.01)$. At an experimental goiter that indicator grew approximately to the same degree - on $43.4 \% \quad(P=0.002)$. The disturbance of a functional-morphological condition of a thyroid gland and an orthodontic intervention promoted to increase of GPA in bone tissue of an alveolar process on $73.4 \% \quad(P=0.001)$. However, in those animals the value of GPA certainly exceeded to the level of the same value in healthy rats with OTM $\left(P_{1}<0.05\right)$. Also in the case of an experimental goiter without OTM $\left(P_{2}=0.02\right)$. It was confirmed worsening of degradation of proteins in bone tissue under the activity of orthodontic forces on the background of a goiter. Fixation of a closing spring to healthy rats also led to the substantial increase of another proteolytic enzyme activity in an alveolar bone - elastase ( $\mathrm{pH}$ 6.5). An experimental goiter didn't promote the accurate change of that value $(P>0.2)$. Thus associative modeling of a goiter and an orthodontic intervention caused more substantial growth of an elastase activity in an alveolar bone of animals $(\mathrm{P}=0.002)$ (Table 3$)$.

\section{Phosphatases activity of an alveolar bone}

The research results of the phosphatases activity of an alveolar bone of experimental animals are generalized in the Table 4. Orthodontic teeth transfer in healthy animals induced substantial growth of AcP activity in an alveolar bone. A goiter reproduction led to increasing that value to $5.48 \pm 0.51 \mathrm{mc}-\mathrm{cat} / \mathrm{g}$, the combination of a goiter and OTM - to $8.70 \pm 0.45 \mathrm{mc}-\mathrm{cat} / \mathrm{g}$. Morphological and functional disturbances of a thyroid gland led to an intensification of resorptioned processes in bone tissue of an alveolar process in rats with OTM. Along with the augmentation of AcP activity in bone tissue of an alveolar process of rats, which were modeled by teeth transfer or a goiter, AIP activity increased of $31.6 \%$ on average. At combination AlP activity increased more considerably - of $79.6 \%$.

\section{Discussion}

Thyroid hormones are the factors regulating and supervising processes of bone remodeling and mineral exchange $[4,5,12,13]$. The majority of researches are devoted to influence of thyroid hormones on kinetics and biomechanics of orthodontic teeth transfer [14-16]. At the increased concentration of thyroid hormones rate of teeth transfer is enlarged, at reduction - is decreased [17]. Our research has been devoted to studying of influence of orthodontic tooth movement on the background of the disturbance of a thyroid gland function on the activity of bone phosphatases and proteinases.

Table 3. Influence of an experimental goiter and orthodontic intervention on activity of proteinases of rats' alveolar bone

\begin{tabular}{|c|c|c|c|}
\hline \multicolumn{2}{|c|}{ Groups of animals } & The general proteolytic activity, nkat/kg & Activity of elastase, $\mathrm{mk}-\mathrm{kat} / \mathrm{g}$ \\
\hline \multirow{2}{*}{ The intact } & Without OTM & $29.86 \pm 2.89$ & $3.65 \pm 0.44$ \\
\hline & OTM & $43.59 \pm 3.16^{1}$ & $4.87 \pm 0.39^{1}$ \\
\hline \multirow{2}{*}{ Experimental goiter } & Without OTM & $42.99 \pm 1.85^{1}$ & $4.40 \pm 0.28$ \\
\hline & OTM & $51.79 \pm 2.45^{123}$ & $5.76 \pm 0.35^{13}$ \\
\hline
\end{tabular}

Table 4. Influence of an experimental goiter and orthodontic intervention on activity of phosphatases of rats' alveolar bone

\begin{tabular}{|c|c|c|c|}
\hline \multicolumn{2}{|c|}{ Groups of animals } & Activity of acidic phosphatase, $\mathrm{mk}-\mathrm{kat} / \mathrm{g}$ & Activity of alkaline phosphatase, $m k-k a t / g$ \\
\hline \multirow{2}{*}{ The intact } & Without OTM & $3.51 \pm 0.24$ & $81.75 \pm 6.10$ \\
\hline & ОтМ & $4.36 \pm 0.18^{1}$ & $109.87 \pm 8.09^{1}$ \\
\hline \multirow{2}{*}{ Experimental goiter } & Without OTM & $5.48 \pm 0.51^{1}$ & $105.31 \pm 9.27^{1}$ \\
\hline & OTM & $8.70 \pm 0.45^{123}$ & $146.82 \pm 12.25^{123}$ \\
\hline
\end{tabular}


Results of the research have testified that modeling of orthodontic teeth transfer, especially in animals with an experimental goiter provokes resorption of bone tissue of a mandible and development of teeth caries. It is compounded with the data of experimental research of D.S. Feitosa et al. [18], which has shown that at hypothyroids "loss" of bone mass were enlarged and the number of TRAP-positive cells was enlarged on a linear surface of a bone crest. Thus any essential differences in comparison with the control haven't been revealed concerning the quality of a trabecular bone of an alveolar process and number of TRAP-positive cells in its structure. Our researches have shown the intensity of carious process to a less degree depends on an orthodontic intervention as neither the quantity, nor depth of carious lesions were not enlarged in healthy rats whom were fixed orthodontic springs.

As it is known, activity of AcP and AlP of rats' incisors pulp reflects a functional condition of a pulp. AlP is responsible for mineralization of hard tooth tissues, and AcP - takes part in resorption (demineralization) of dentine and enamel [19, 20].

Increase of AcP activity in a pulp show intensification of resorptioned processes in hard tissues of rats' teeth, it is the most expressed in animals with a goiter and OTM. It is necessary to notice that the reduction of AIP activity in animals with modeling of a goiter and OTM is less appreciable, than augmentation of ACP activity. On the basis of it, it is possible to conclude that aggravation of carious process in rats at modeling of teeth transfer or on the background of an experimental goiter occurres basically at the expense of intensifying of resorptioned processes, instead of at the expense of oppression of remineralization of hard teeth tissues.

The important component of resorption of bone tissue is degradation of an albuminous matrix under the influence of proteolytic enzymes, which operates stage by stage at various value of $\mathrm{pH}[20,21]$. In connection with registration of intensifying of atrophy of an alveolar bone in rats under the influence of the orthodontic forces, the most expressed on the background an experimental goiter was of interest researches of general proteolytic activity of GPA ( $\mathrm{pH} 7.6)$ and activity of the most powerful destructive enzyme of elastase $(\mathrm{pH} \mathrm{6.5)}$ in bone tissue of an alveolar process. The augmentation of activity of proteinases showed aggravation of degradation of protein of bone tissue at fixation of orthodontic springs on the background of a goiter. These results are proved by more appreciable degree of atrophy of an alveolar bone in rats with OTM and by an experimental goiter.

Expression augmentation of osteocalcin, alkaline phosphatase and osteal morphogenetic proteins is established at action of thyroid hormones [22-24]. As activity of osteal AlP grows at an intensification of processes of mineralization and in our research intensifying of resorption in an alveolar bone at reproduction of a goiter or orthodontic teeth transfer is revealed, it is possible to explain the registered increase of AIP activity by compensatory reaction on action of the general and local factors. And the combination of these factors aggravates augmentation of AIP activity as well as AcP activity and proteolytic enzymes in bone tissue of an alveolar process.

\section{Conclusion}

Thus, the received results of research show that in experimental animals on the background of functional and morphological disturbances of a thyroid gland orthodontic tooth transfer is accompanied by sharp aggravation of resorption processes of bone tissue of an alveolar process, demineralization of hard tooth tissues. Increasing of the proteinases activity of bone tissue and the disturbance of bone phosphatases activity testify about it. Hence, children with thyroid gland diseases need carry out of active treatment-and-prophylactic measures at stages of active apparatus treatment of maxillodental anomalies. It will allow avoiding the complication at orthodontic treatment, such as focal demineralization of enamel, digestsention and fenestration of an alveolar bone. The further researches are necessary for the purpose of working out the strategy of complex orthodontic treatment for the category of children to take into account the stomatologic status and the main disease.

\section{Acknowledgments}

We are grateful to Professor A.A. Babanin (rector of Crimean State Medical University n.a. S.I. Georgievsky), Professor K.N. Kosenko (director of Institute of Stomatology of Ukrainian Academy of Medical Sciences), and Professor A.P. Levitsky for the opportunity to carry out experimental research.

Conflict of interest: none declared.

\section{References}

1. Shimura H. Epidemiology of thyroid disease. Nihon Rinsho 2012; 70 (11): 1851-1856. (PMID: 23214052)

2. Buriak VN, Murashko ES. Peculiarities of thyroid pathology in the childhood. Lik Sprava 2012; 5: 58-63. (PMID: 23534272)

3. Li M, Eastman CJ. The changing epidemiology of iodine deficiency. Nat Rev Endocrinol 2012; 8 (7): 434-440. (doi: 10.1038/nrendo.2012.43) (PMID: 22473332)

4. Bassett JH, O'Shea PJ, Sriskantharajah S, Rabier B, Boyde A, Howell PG. Thyroid hormone excess rather than thyrotropin deficiency induces osteoporosis in hyperthyroidism. Mol Endocrinol 2007; 21: 1095-1107. (PMID: 17327419)

5. Bassett JHD, Williams AJ, Murphy E, Boyde A, Howell PGT, Swinhoe R. A lack of thyroid hormones rather than excess thyrotropin causes abnormal skeletal development in hypothyroidism. Mol Endocrinol 2008; 22:501-12. (PMID: 17932107) (PMCID: PMC223458).

6. Povoroznyuk VV, Gopkalova I.V. Age-dependent features of bone mineral density changes in male rats with hyperthyroidism. Endocrine Abstracts 2010; 22: OC6.3.

7. Van Beek H. Risks of orthodontic treatment. Ned Tijdschr Tandheelkd 2009; 116(6): 306-310. (PMID: 19585883)

8. Yu K, Narayanan L, Mattie D. The pharmacokinetics of perchlorate and its effect on the hypothalamus-pituitary-thyroid axis in the male rat. Toxicol Appl Pharmacol 2002; 182(2): 148-159. (PMID: 12140178)

9. Mishunina TM, Bogdanova TI, Kalinichenko OV, Pilkevich LI. The characteristic of experimental models of a goiter in rats. Endokrinol 2005; 10(2): 194-200.

10. Levitsky AP, Marchenko Al, Denga OV. Experimental methods of research of stimulators of osteogenesis. Kiev, 2005. [Book in Russian]

11. Visser L, Blout ER. The use of p-nitrophenyl-N-test-butyl-oxycarbonyl-Ialaninate as subsrate for elastase. Biochim Biophys Acta 1972; 268(1): 275-280. (PMID: 5062949)

12. Kanatani M, Sugimoto $T$, Sowa $H$, Kobayashi $T$, Kanzawa M, Chihara K. Thyroid hormone stimulates osteoclast differentiation by a mechanism independent of RANKL-RANK interaction. J Cell Physiol 2004; 201: 1725. (PMID: 15281085)

13. Zofková I. Hormonal aspects of the muscle-bone unit. Physiol Res 2008; 57 (Suppl 1): S159-S169. (PMID: 18271680) 
14. Shirazi $M$, Dehpour AR, Jafari $F$. The effect of thyroid hormone on orthodontic tooth movement in rats. J Clin Pediatr Dent 1999; 23: 259264. (PMID: 10686873)

15. Verna C, Dalstra M, Melsen B. The rate and the type of orthodontic tooth movement is influenced by bone turnover in a rat model. Eur J Orthod 2000; 22: 343-352. (PMID: 11029824)

16. Verna C, Melsen B. Tissue reaction to orthodontic tooth movement in different bone turnover conditions. Orthod Craniofac Res 2003; 6: 155-163. (PMID: 12962198)

17. Tyrovola JB, Spyropoulos MN. Effects of drugs and systemic factors on orthodontic treatment. Quintessence Int 2001; 32: 365-371. (PMID: 11444068)

18. Feitosa DS, Marques MR, Casati MZ, Sallum EA, Nociti FH Jr, de Toledo $S$. The influence of thyroid hormones on periodontitis-related bone loss and tooth-supporting alveolar bone: a histological study in rats. $J$ Periodontal Res 2009; 44 (4): 472-478. (PMID: 18973522) (doi: 10.1111/j.1600-0765.2008.01144)

19. Anderson H C, Morris D C. Mineralization. Handbook of Experimental Pharmacology 1993; 107: 267-98 (doi: 10.1007/978-3-642-77991-6_8)

20. Bull H, Murray PG, Thomas D, Fraser AM, Nelson PN. Acid phosphatases. Mol Pathol 2002; 55(2): 65-72. (PMID: 1195095) (PMCID: PMC1187150)

21. Everts V, Delaissé JM, Korper W, Niehof A, Vaes G. Degradation of collagen in the bone-resorbing compartment underlying the osteoclast involves both cysteine-proteinases and matrix metalloproteinases. $J$ Cell Physiol 1992; 150(2): 221-231. (PMID: 1734028)

22. Akalin A, Colak O, Alatas O, Efe B. Bone remodelling markers and serum cytokines in patients with hyperthyroidism. Clin Endocrinol 2002; 57: 125-129. (PMID: 12100080)

23. Kanno $Y$, Ishisaki A, Yoshida M, Nakajima K, Tokuda H, Numata O. Adenylyl cyclase-cAMP system inhibits thyroid hormone-stimulated osteocalcin synthesis in osteoblasts. Mol Cell Endocrinol 2005; 229: 7582. (PMID: 15607531)

24. Lassova L, Niu Z, Golden EB, Cohen AJ, Adams SL. Thyroid hormone treatment of cultured chondrocytes mimics in vivo stimulation of collagen X mRNA by increasing BMP 4 expression. J Cell Physiol 2009; 219: 595-605. (doi: 10.1002/jcp.21704) (PMID: 19170125)

\section{Authors:}

Kamila A. Kolesnik - MD, PhD, Associate Professor, i) Head of Department of children's stomatology, Crimean State Medical University n.a. S.I. Georgievsky, Simferopol,Ukraine; ii) Freelancer, Institute of Stomatology of Ukrainian Academy of Medical Sciences; Odessa, Ukraine;

Oksana Denga - MD, D.Sc., Professor, Head of Department of children's stomatology, Institute of Stomatology of Ukrainian Academy of Medical Sciences, Odessa, Ukraine;

Olga Makarenko - D.Sc., Head of biochemical laboratory, Institute of Stomatology of Ukrainian Academy of Medical Sciences; Odessa, Ukraine. 